Practice Report: Clinic, the University and Society

\title{
Live Client Clinics: Bridging the Gap
}

Nicola Antoniou and Patrick Hassan-Morlai ${ }^{1}$,

University of East London, UK

n.antoniou@uel.ac.uk p.hassan-morlai@uel.ac.uk

\begin{abstract}
There has been a shift in attitudes towards clinical learning as part of the student learning experience at universities. ${ }^{2}$ Some modern Universities ${ }^{3}$ in the United Kingdom now integrate practical based learning in their law degree programmes. ${ }^{4}$ Kingston University London offers credits to its students as part of their law degree for participating in its law clinic. The view the University of East London (UEL) adopts in preparing students for the world beyond the university is that "Students do not deserve to be handed a flat-pack degree without any extras - they deserve a fully rounded education and that is what they will get if they come [to UEL]." 5 UEL's Law Clinic is a central vehicle to achieving this aim.
\end{abstract}

\footnotetext{
${ }^{1}$ Nicola is Lecturer and Law Clinic Supervisor and Patrick is Lecturer and Law Clinic Director at the University of East London's Law Clinic, lawcentre@uel.ac.uk

2 University of Greenwich, University of Huddersfield, University of Westminster, are among the recent entrants to clinical legal education by opening new law clinics in 2013/2014.

${ }^{3}$ Following the enactment of the Further and Higher Education Act 1992, the terms: modern universities, new universities and post-1992 universities became part of the lexicon to describe the 35 polytechnics that were transformed to or conferred university status in the United Kingdom. ${ }^{4}$ The provision of law clinic is still voluntary for law schools in the UK just like it is in the USA. US law schools are not required by the American Bar Association (ABA) to provide clinical legal education as part of law schools obligation to provide "substantial instruction in ... professional skills generally regarded as necessary for effective and responsible participation in the legal profession" [and] "substantial opportunities for live-client or other reallife practice experiences." See Standards 302(a)(4), 302(b)(1) of the ABA Section of Legal Education and Admissions to the Bar, ABA Standards for Approval of Law Schools 18-20 (2005-06) cited by Weigold, U. H. (2006) The Attorney-Client Privilege as an Obstacle to the Professional and Ethical Development of Law Students, Pepperdine Law Review, Volume 33 (3), pp 676-722 at 688.

${ }^{5}$ Statement of Professor Patrick McGhee, (former) Vice-Chancellor and Chief-Executive of UEL, July 2011.
} 
This practice-based paper looks at the development of our Law Clinic, which is a live client clinic, how it works in practice and includes a breakdown of statistics in demographics and advice areas. We present a selection of cases as well as extracts from students and clients' testimonials.

Drawing on the benefits from our clients and experience of our students, this paper concludes that the experience gained from working in the Law Clinic should be integrated into the academic content of the law school. We suggest that live clinics increase the quality and experience of our students' learning.

\section{INTRODUCTION}

If graduates are to meet the expectations of employers, then universities should acknowledge the virtue of learning by doing. Confucius, the great Chinese thinker, political philosopher and educator $(551-479 \mathrm{BC})$ once said these words about the value of experiential learning (i.e. learning by doing): "By three methods we may learn wisdom: first, by reflection, which is noblest; second, by imitation, which is easiest; and third by experience, which is the bitterest."6

Although Confucius' model involves 'imitation' (which could arguably fit in with simulation $^{7}$ clinic work), the full effects of experiential learning must involve reflection and experience. Professor Jeff Giddings calls live clients 'real clients' and says "[t]he complexity of working with real clients should be seen as the logical

\footnotetext{
${ }^{6}$ Cited by Hinett, K. (2002) Developing Reflective Practice in Legal Education (edited by Tracey Varnava), Coventry: UK Centre for Legal Education, Preface page.

${ }_{7}$ Simulation here is taken to mean as a form of clinical legal education where "students assume lawyer roles, usually involving the representation of hypothetical clients", Professor Adrian Evans, Monash University, Associate Professor Anna Cody, University of New South Wales, Ms Anna Copeland, Murdoch University, Professor Jeff Giddings, Griffith University, Associate Professor Mary Anne Noone, La Trobe University, and Associate Professor Simon Rice, Australian National University (2012), Report on Best Practices, Australian Clinical Legal Education (September 2012), p 4.
} 
progression of other studies involving the incremental development of practicerelated skills and understanding." ${ }^{8}$ In this regard, we share the view of Ursula H. Weigold in observing that 'Simulations are not a substitute for live-client interactions, even though they certainly can add value to traditional law school teaching methods. Role playing, even with skilled actors, does not have the feeling of reality and therefore does not demand as much from students as does live-client work. Simulation does not involve the level of responsibility for results that live-client experience entails. "Even the best simulationbased courses... provide make believe experiences with no real consequences on the line. Simulation also lacks the complexity that leads to the depth of learning possible in experiences involving real clients. "We cannot be said truly to understand anything until we understand it in context and in complexity. ${ }^{\prime 9}$

Robert and Farideh suggest that two highly effective experiential methods are livecase study projects and internships. The results of their study found that prior internship experience improve applied project learning outcomes and integrated skills and knowledge. ${ }^{10}$

Most, if not all, forms of experiential learning ${ }^{11}$ enable students to acquire valuable skills and experience. This is because for over 100 years, most if not all undergraduate legal education is exclusively delivered via the 'case method' of

\footnotetext{
8 Giddings, J. (2010) Why No Clinic Is an Island: The Merits and Challenges of Integrating Clinical Insights Across the Law Curriculum, Journal of Law and Policy, Volume 34, pp 261-289 at 262.

9 Weigold, U.H. (2006) The Attorney-Client Privilege as an Obstacle to the Professional and Ethical Development of Law Students, Pepperdine Law Review, Volume 33 (3), pp 676-722 at 691. ${ }^{10}$ Robert, D.G., \& Farideh, A.F. (2012) Experiential learning: The internship and Live-Case Study Relationship: Business Education and Accreditation, Volume 4(1), pp 13-23.

11 These include law clinic, internship, placements, simulation, etc.
} 
teaching law. ${ }^{12}$ The use of case method in legal education focuses on case analysis to identify legal principles from decided cases and to apply those principles to problem questions or essay writing to test the students' knowledge and understanding of the law. It has been suggested that the exclusive use of analytical tools in the case method of legal education creates a skills gap in students. ${ }^{13}$ Skills such as managing file, conducting client interviews, drafting legal documents and legal advice, etc. which are clearly essential in a lawyer's practice are not routinely taught as part of the undergraduate law degree. This creates gaps in law students' skills acquisition and preparation to enter the world of work or to pursue the vocational stage of their training to become a lawyer. Therefore, the experience gained from working in a live client clinic for example, bridges this skills gap.

\section{THE DEVELOPMENT OF THE LAW CLINIC AT UEL}

UEL established its Law Clinic to help the local East London community (renowned for its low socio-economic status compared with other affluent London boroughs ${ }^{14}$ ) by offering free legal advice. The Law Clinic was also created to enable our students to acquire legal work experience within a supervised environment. This facility enables our students to learn and practise the virtues of pro bono work for those members of the public who are unable to pay for legal advice and/or cannot get legal

\footnotetext{
${ }^{12}$ Ferguson, D.D. (2013) The State of Experiential Education in Canadian Law Schools, Manitoba Law Journal, Volume 37 (1), pp $465-471$, at 468.

${ }^{13}$ Ibid., pp 466 \& 468.

${ }^{14}$ London Poverty Profile 2013 available at http://www.londonspovertyprofile.org.uk/LPP 2013 Report Web.pdf or http://www.londonspovertyprofile.org.uk/LPP 2013 Findings Web.pdf (last accessed 01/04/2014).
} 
aid to receive legal advice. The current phase of UEL's Law Clinic was launched in March 2010 and it started offering free legal advice in April 2010. ${ }^{15}$ But for the services our Law Clinic offers, some of our clients would not have had access to any form of legal advice.

\section{Faculty and student attitudes}

UEL provides staff at the Law Clinic a tremendous degree of autonomy and supports the Law Clinic with adequate resources to undertake its activities. The Law Clinic has not yet been able to obtain external funding and in the interim, the University provides all its running costs including employing one full-time and one part-time member of staff. As a local university to East London, UEL is always finding ways of making itself relevant to its students, staff and local community by providing free services and facilities wherever possible. For example, UEL regularly engage in campaigning that generate positive social change. UEL has been part of the London Living Wage campaign and is the first university to ban payday loan marketing within its campuses. The establishment of UEL's Law Clinic is a further demonstration of the UEL's civic engagement programme to benefit both our local community and students. In addition, the funding to build University Square Stratford (the new home of our School of Business and Law) was secured partly because of our Law Clinic's services to the local community.

\footnotetext{
${ }^{15}$ New Law Clinic at UEL offers legal advice to the local community (2014) available at http://www.uel.ac.uk/news/press-releases/2010/03/community.htm (last accessed 01/04/2014).
} 
UEL law students have come to appreciate the value of gaining experience in the Law Clinic. They demonstrate this by applying in big numbers to volunteer in the Law Clinic. Recruitment is done through an open and competitive process whereby all law school students are encouraged to apply. Our student volunteers also take an active role in organising our public legal education lectures.

\section{How our live client clinic works}

UEL's Law Clinic provides pro bono legal advice to members of the East London community. This service is provided by students under the supervision of professionally-qualified members of staff. The Law Clinic therefore offers students in the School of Law and Social Sciences the opportunity to take part in hands-on legal work for the mutual benefit of the students and the wider community.

Our student advisers undertake a variety of roles including opening files, conducting clients' interviews, preparing case notes, researching the legal issues of cases, and drafting advice letters. We support and supervise students' work at every stage. For example, student advisers meet with their allocated Supervising Solicitor before and after a client interview to discuss issues in the case. The students will also meet with their Supervising Solicitor after their legal research and initial draft advice letter to consider, amend or approve before it is sent to a client.

We also have external solicitors volunteering their time and expertise. Our Supervising Solicitors are always present during our interview and advice sessions. 
Our Law Clinic also has an administrator who supports both student and external volunteers to ensure the smooth-running of the Law Clinic.

The Law Clinic offers its services via three main routes

Appointment-only advice service - Our students schedule clients' appointments and conduct interviews during normal office hours on weekdays during term-time. The times for these appointments, are decided by a Supervisor or the Director in consultation with the student advisers. Once an appointment has been booked the allocated student adviser would open a file and draft and send an appointment confirmation letter to the client.

Evening Drop-in advice service - The Law Clinic also runs a drop-in advice service. In 2013/2014 the drop-in service was delivered on Wednesdays from 6pm-9pm. The 2014/2015 drop-in service will run on Thursdays from 6pm-8pmThis service also runs during term-times only. Our external solicitor volunteers attend our drop-in service.

Public Legal Education project ("Know the Law") - Members of our community need not have a legal problem to know the law and so this project provides generic legal information and education to the public. This project hosts free public lectures on current, sensitive and engaging legal topics that are open to members of the public including solicitors, lecturers, students, teachers, and police officers. Our public lectures now carry Continuing Professional Development (CPD) points as our Law Clinic has been approved by the Solicitors Regulation Authority (SRA) as an External CPD Provider. Therefore legal professionals and solicitors in particular who 
attend these lectures can claim CPD points. This project is part of the UEL's civic engagement agenda. ${ }^{16}$

Our first CPD public lecture in June 2014 was delivered by Baroness Doreen Lawrence and Dr Imran Khan (who is the patron of our Law Clinic) on the topic: "Police Corruption, Inappropriate Undercover Policing and Spying on Victims' Families: The Stephen Lawrence Independent Review 2012-14 - meaning and impact". The Law Clinic also held a public lecture when it was re-launched in November $2013 .{ }^{17}$ Sir Robin Wales, Mayor of Newham delivered the keynote address on the legacy of the Olympics and the value of volunteering. In February 2014 the Law Clinic held another public lecture on "The law on drugs offences, knife offences, and the principle of joint enterprise." The lecture was delivered by solicitors from a leading criminal practice Sonn Macmillan Walkers based in London.

\section{Current areas of law}

We advise on the following areas of law:

i. Landlord and tenant disputes

ii. Employment issues

iii. Contract and Consumer transactions

iv. Social security / welfare benefits

v. Debt advice (limited to the aims of our project called 'Be Creditworthy', namely guidance about how to stay in credit).

\footnotetext{
${ }^{16}$ UEL works towards being a leader in civic engagement and offers learning and advice and campaigns on issues that generate positive social change.

${ }^{17}$ Human Rights Lawyer Imran Khan re-launches UEL Law Clinic (2013) available at http://www.uel.ac.uk/news/press-releases/2013/11/law-clinic.htm (last accessed 29/11/2013).
} 
vi. Family law

vii. Any other matter that comes through our drop-in advice session that we are able to provide generic information or referral services.

\section{Training}

Our student advisers receive training in the above areas of law and this training is provided by staff of the Law Clinic. Our student advisers are also able to access the free CPD accredited training provided by LawWorks, one of our external partners ${ }^{18}$. These are short courses on relevant areas of law.

We also provide in-house training on clients' interviews, procedures to follow after an interview, legal research, drafting advice letters, time-keeping and recordkeeping. As part of the training we advise our students to keep accurate, contemporaneous and up-to-date record so that anyone who picks up their file can readily understand it.

The following checklist is a brief summary of what is expected of our students:

- Case details received by students and Supervisor / Director

- Prepare and keep research trail

- Pre interview meeting with students and Supervisor / Director

- Interview with client

- Post interview meeting with students and Supervisor / Director

- Students draft advice letter

- Advice letter checked by Supervisor / Director

- Advice letter returned to students to perfect and to be signed by students and Supervisor/ Director

\footnotetext{
${ }^{18}$ http://www.lawworks.org.uk/
} 
- Letter of advice sent to client

- Follow-up/case work

\section{Students' roles and conduct}

All students sign a volunteer agreement, which requires the students to confirm that they have read and understood all of the rules and policies in the Handbook provided to them and agree to abide by them.

\section{Professional and ethical matters}

We set out very clearly to our students that we owe a duty to provide a competent and professional service to all clients. Although our Law Clinic is not regulated by the SRA, we aspire to comply with the professional rules and code of conduct of the SRA. All students at the Law Clinic will be working on client matters under the supervision of solicitors who hold practising certificates. Students are advised to familiarise themselves with potential professional issues such as conflict of interests and client confidentiality.

\section{Learning through doing and feedback}

Although the Law Clinic provides a useful service to clients, its main purpose is to aid students' learning. Self-evaluation is a vital part of this process. We therefore ask all students to complete an evaluation form, which asks students to think about what they have achieved, what they could have done better and what they might have done differently. This evaluation also assists Supervisors. Students are also required to take part in a group evaluation meeting with other participants to 
discuss in general terms their involvement in the Law Clinic. Students are told that learning from the experience of others is as important as reflecting on their own work. Such meeting takes place at the end of the semester.

Supervising Solicitors undertake file reviews and case management for each case and file that is worked on. The Law Clinic recently employed a legal administrator who is a former student at UEL. Our legal administrator helps with the file reviews and undertakes checks on completion and ensures that any outstanding matters or tasks are completed expeditiously and with diligence. Each student is given a checklist so that they can see what needs to be achieved and completed before the file can be closed.

At the end of each advice session Supervising Solicitors will feedback on the students' performance during the interview and meetings.

Once advice letters are complete students also receive detailed feedback and suggested amendments from Supervising Solicitors on the quality of the advice letter.

\section{Resources}

We have a number of resources at the Law Clinic that are available to students in order to carry out research and draft advice letters.

Books

The Law Clinic has a collection of practice books which provide analyses of the practical application of law. 
The Law Clinic has a database of advice letters to act as a template or precedent for the purpose of continuity.

Lexis PSL

This is an online database of legal resources provided by LexisNexis, which is designed specifically for free legal advice centres / legal practices. LexisNexis through LawWorks provides us this resource free of charge.

\section{AdviserNet}

This is a subscription CD-Rom/online based resource purchased from Citizens Advice and has a large amount of information which is updated monthly. The core topics are:

- Communications

- Travel, transport and holidays

- Immigration and nationality

- Administration of justice

- Education

- Employment

- Discrimination, human rights and government
- Family and personal

- Welfare benefits and tax credits

- Health

- Housing, property and environment

- Taxes

- Consumer, finance and debt

- Leisure

AIMS

This is a case management system where all clients' details are entered and stored. This is very similar to software used by law firms. Students are able to familiarise themselves with this central system and benefit from using a central case management recording system. 
The Law Clinic is typically run like a law firm, which helps introduce our students into a legal work environment. However, we do not hold ourselves out to be a law firm.

\section{Are results actually achieved?}

We provide below our statistics for the academic year 2013/2014 which show the percentages in relation to advice areas and demographics of our clients.

\section{Advice Areas}

- Asylum / Immigration

Business / Charity Services, incl I.P., Insurance etc

- Consumer / Contract

$\square$ Debt and Insolvency

$\square$ Employment

$\square$ Family / Child

$\square$ Housing / Property, incl. Wills and Probate

$\square$ Welfare/Benefits

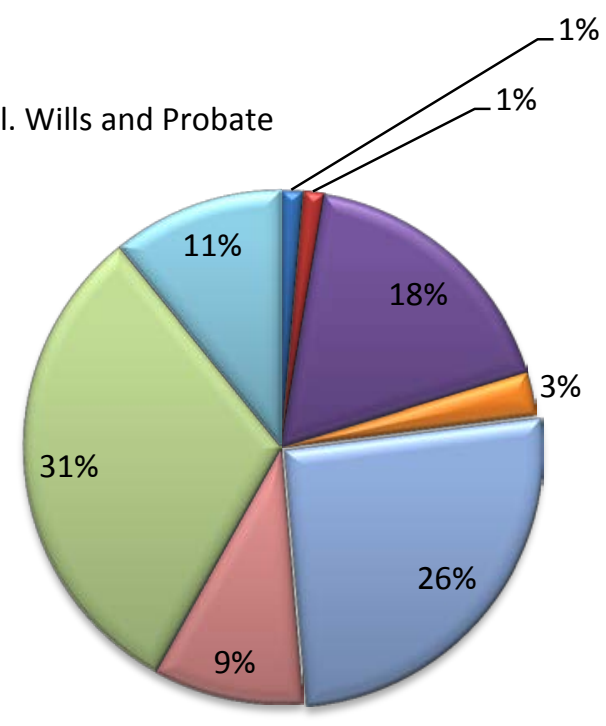

The Law Clinic advised on a number of different areas of law over the past academic year as can be seen from the pie chart above. The most popular areas of law that 
clients seek advice on are housing/property, employment and consumer/contract matters. This is not a surprising result as these are areas in which civil legal aid has now diminished. The Law Clinic has recently been referred family law matters from a local county court. We anticipate that this area of law will be equally as popular over the next academic year.

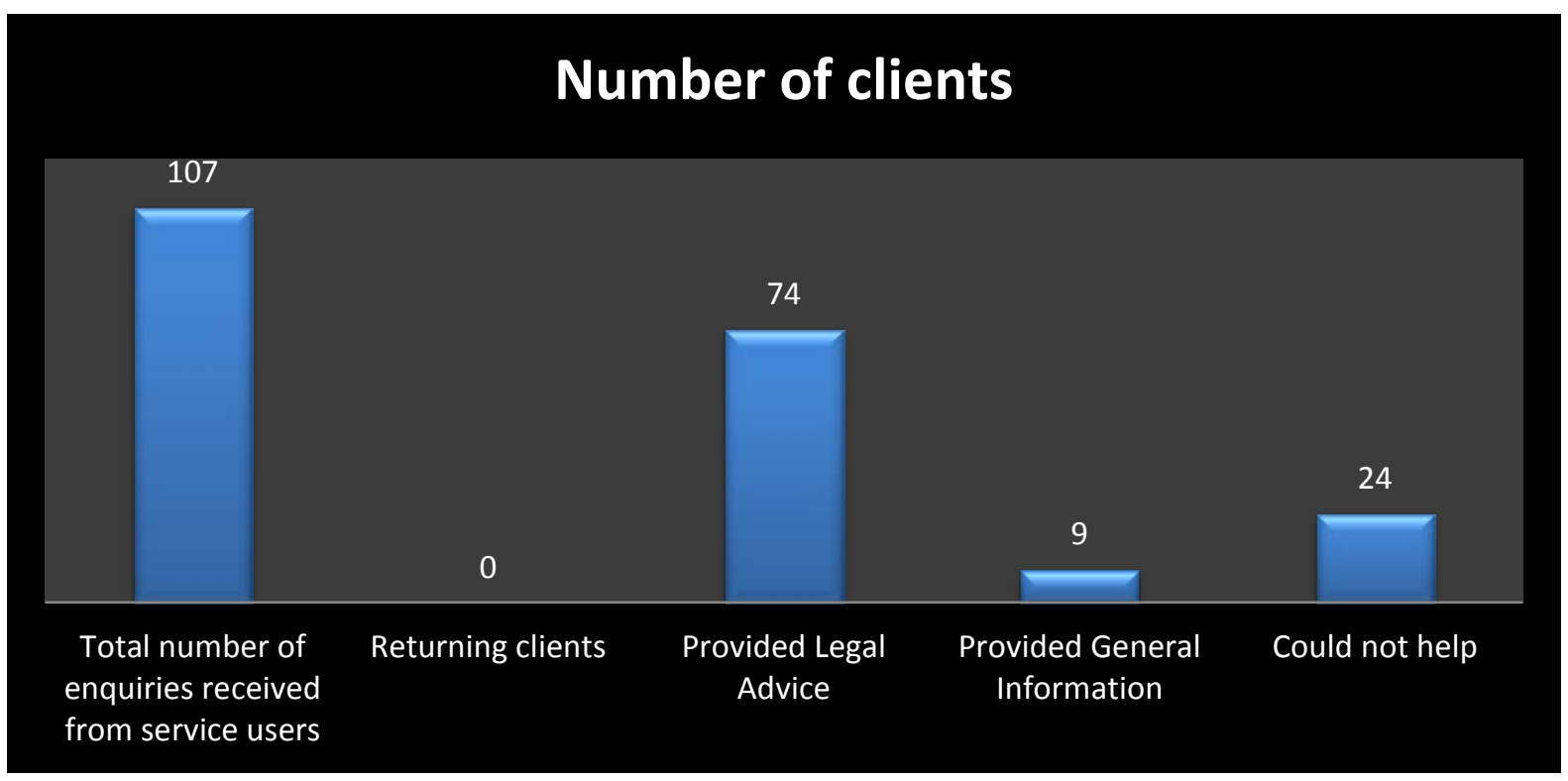

The total number of clients that the Law Clinic saw over the past academic year is 107 clients. This is a significant increase since 2012/2013 academic year, where the Law Clinic only assisted 17 clients. With the introduction of our evening drop-in service, we have seen a dramatic increase in the number of clients who require legal advice. 


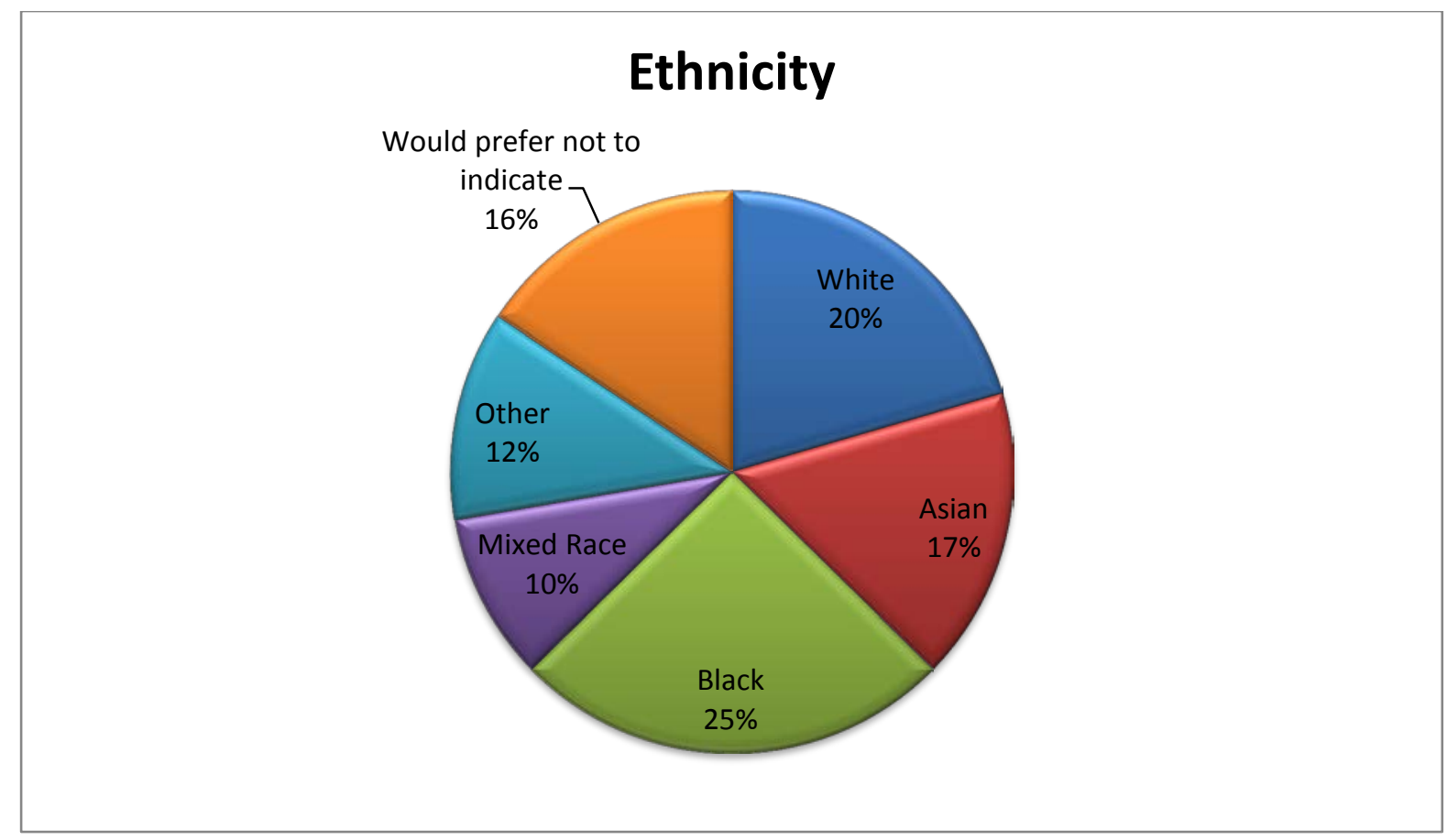

East London is a multi-cultural community, and this is reflective in our clients' ethnicity as indicated above.

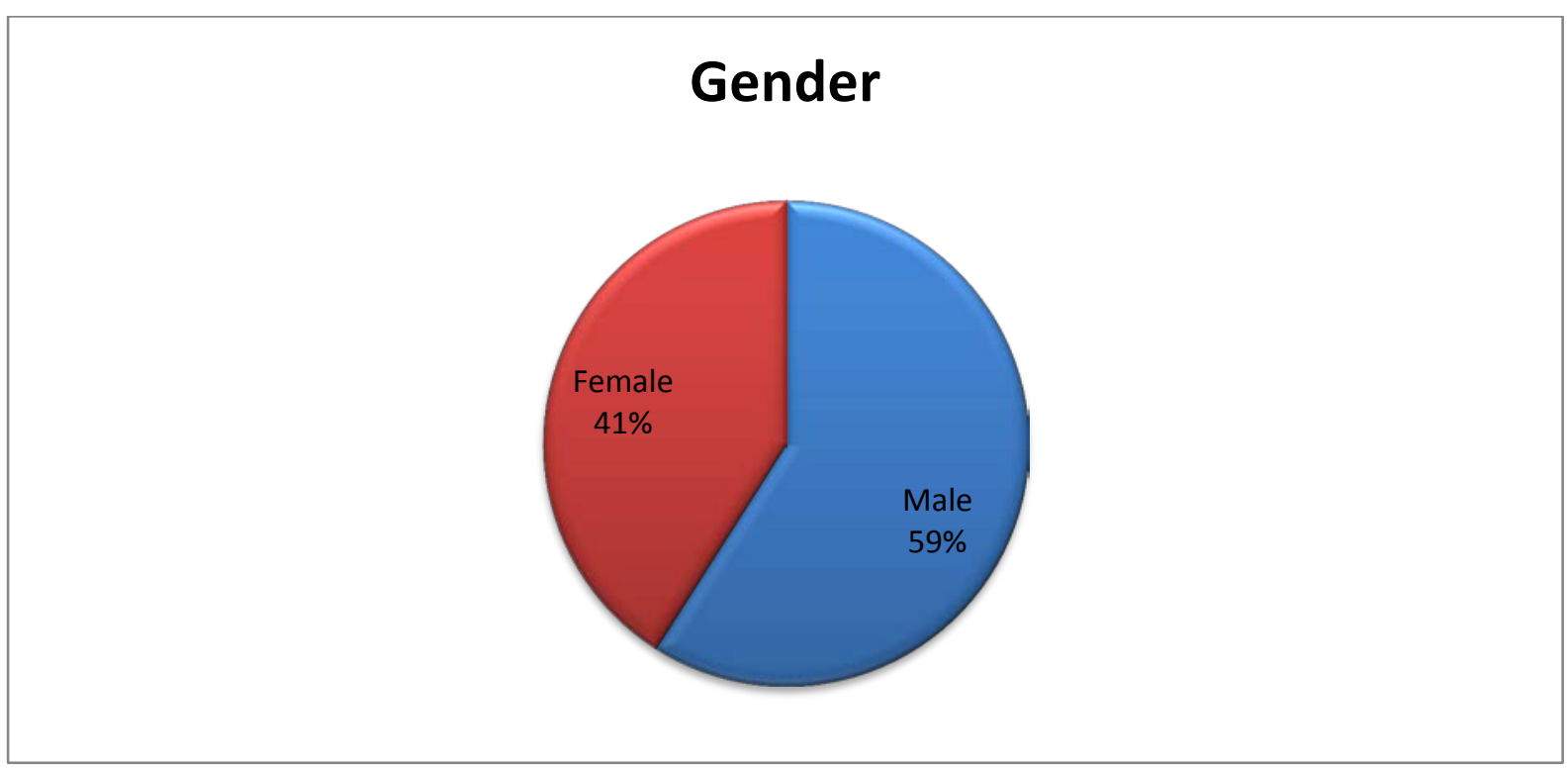

We found that we have advised more men than women at the Law Clinic, although the difference has not been too disproportionate. 


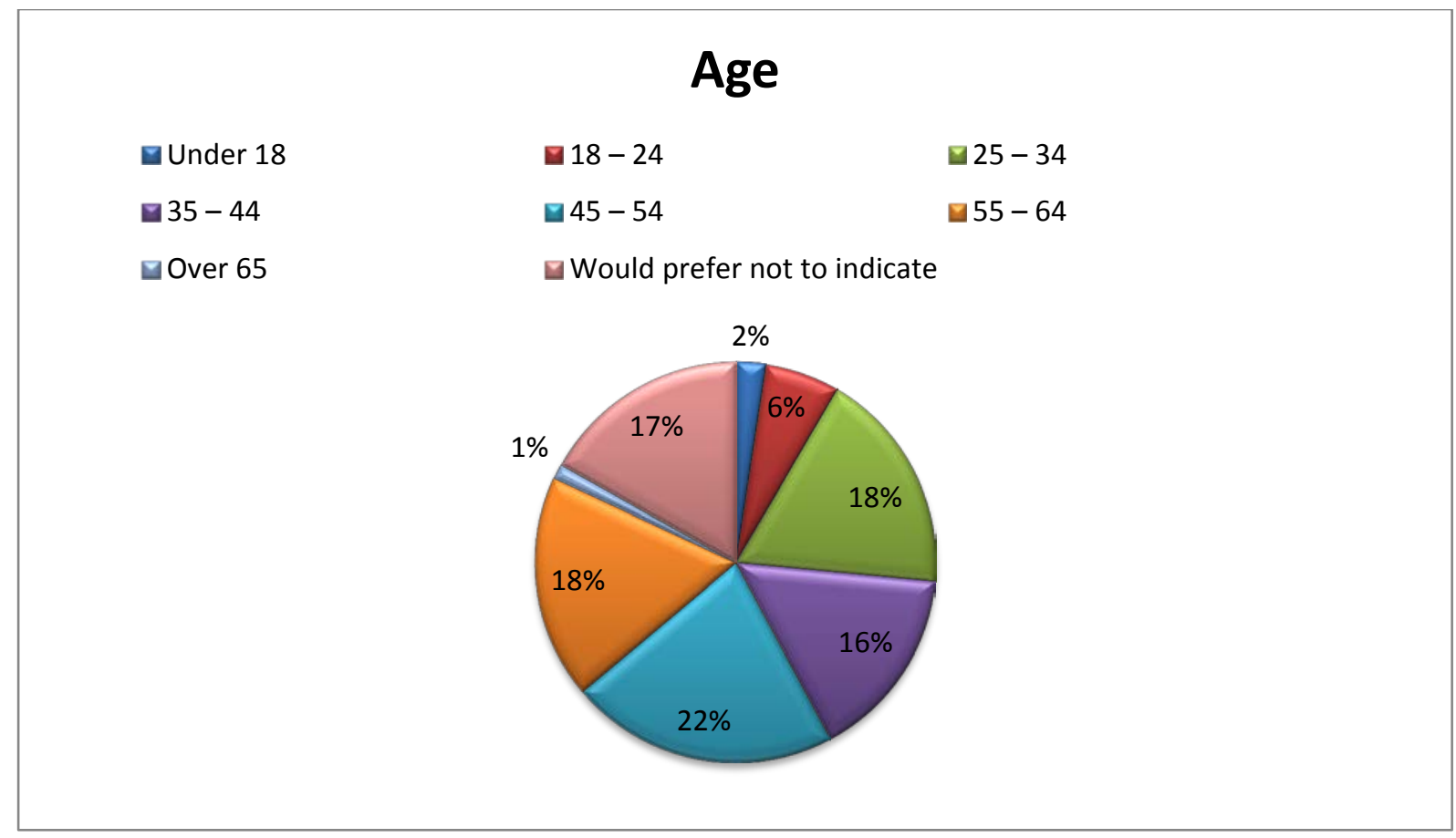

Those aged 45-54 were our largest group of clients. Clients aged between 18-24 and over 65 were less well-represented

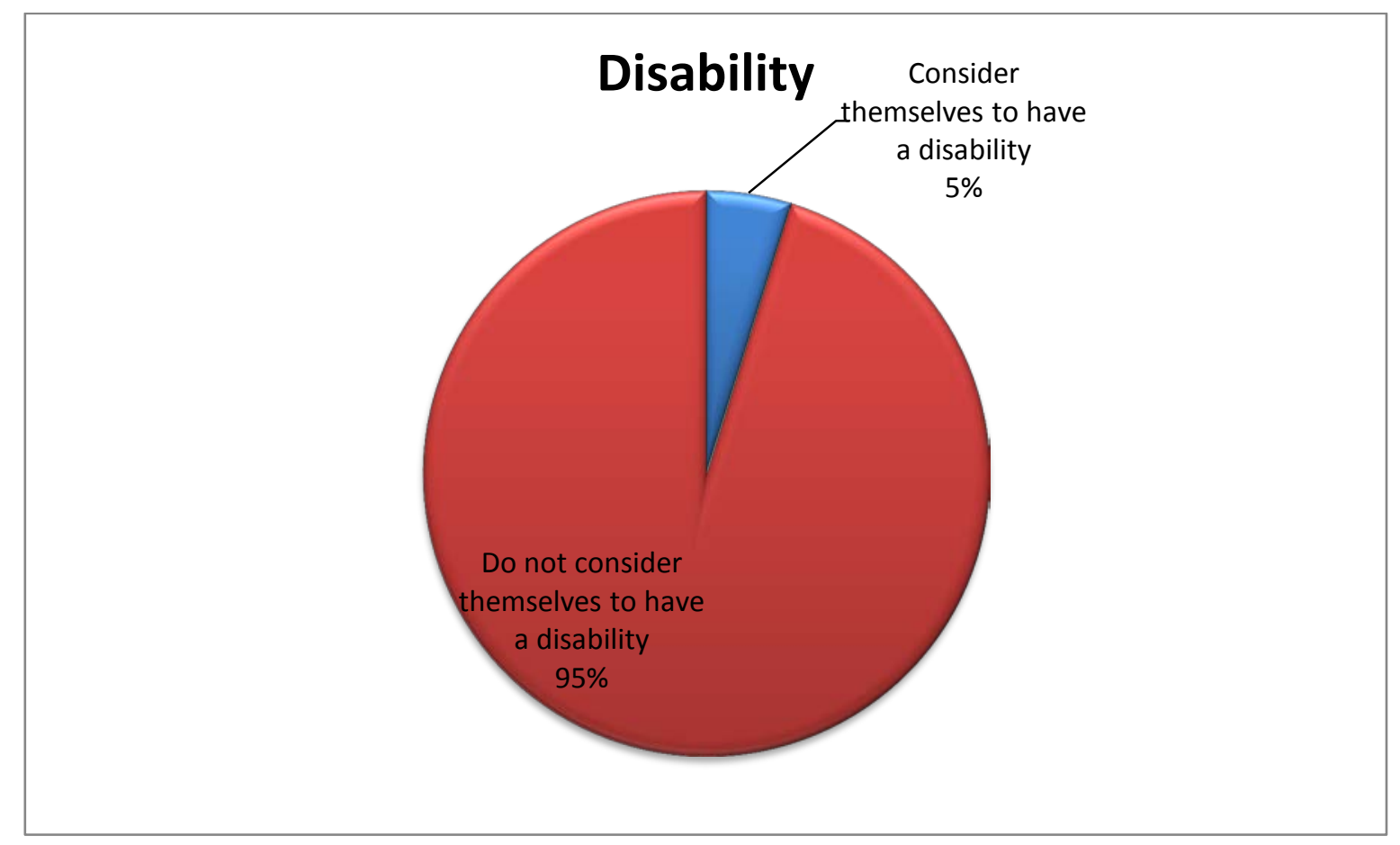

The majority of our clients did not consider themselves to have a disability. 
The Law Clinic at UEL has undertaken a variety of interesting matters and the students have produced some very good results and received positive feedback. Below are a few examples of the cases our student advisers dealt with.

\section{Case 1: Contract and Consumer dispute}

This client had a dispute with one of the world's largest web hosting companies, $1 \& 1$ Internet Ltd. The company had made several demands for outstanding payments for webhosting services and had even passed our client's file to its nominated debt collection agents. Our client disputed the amount and the basis for payment because they believed they had cancelled the contract many months ago.

Our student advisers reviewed the contract documents and were able to ascertain that the client had cancelled the contract and paid off money due for the services used. Our students wrote to the company and its debt collectors and presented their findings of the client's case. Both the company and its debt collectors reviewed the client's case and wrote back to us. The company apologised for the numerous payment demands and explained that those were sent in error on their part. The debt collectors also confirmed that the client had actually paid for all services provided and the file had now been closed. Our client was very pleased with this outcome. 


\section{Case 2: Employment}

This client spoke very limited English and worked as a cleaner. The client felt bullied at work by being asked to carry out manual-handling tasks contrary to their job description. The client felt that a language barrier meant they could not effectively convey their concerns to their employers.

One of our student advisers who speaks fluent Portuguese took the client's instructions and provided the client with initial advice. The Law Clinic took swift action during the interview by telephoning the client's line manager and raising the client's concerns. We followed up this conversation with a letter to the employers. As we had been promised during the telephone conversation, the employers subsequently held an urgent meeting with our client and reassured the client that they would no longer be required to carry out tasks outside the scope of their contract. The client later informed us that their concerns had been resolved to their satisfaction. The client also informed us that they have been extremely happy with our involvement. Our client told us of a new relationship with their employers who have entrusted them with more responsibility and increased pay - a form of promotion, in essence.

Case 3: Landlord and tenant dispute (variation / termination of tenancy agreement)

This client had entered into a tenancy agreement with a landlord's agent. A dispute arose when our client's request for permission to keep their pet in the property was 
refused. Our client felt that they had been treated unfairly as other tenants had been allowed to keep pets in the property.

Our student advisers ascertained that the tenancy agreement provided for tenants to request the landlord's permission to keep pets and that such permission should not be unreasonably refused. Our student advisers wrote to the agents and raised this issue with them and requested the reasons for refusing our client permission to keep their pet when other tenants had been allowed to do so. As instructed, our student advisers also made it clear in their letter to the agents that our client would like to be released from the tenancy agreement and have their deposit returned if permission to keep their pet was refused unreasonably.

We learnt from our client that following receipt of our letter, the agents reviewed their case and resolved the problem. Our client sent us the following email:

"I just want to thank you for your help the other day.

I was in such a difficult situation and you and the legal team really helped me.

The letting agency made contact with me last Friday after receiving the keys and said that they are terminating my contract and will be returning my deposit first thing on Monday morning. I have recently received a cheque from them".

[This extract is reproduced here with the permission of our client].

\section{Case 4: Help with completing county court forms}

This client told us that they were desperate for help with completing their county court forms. They said they had suffered severe physical domestic abuse from their 
spouse and were taking steps to get a divorce. The client was a litigant in person and had submitted their divorce petition for the fourth time. On each occasion, the form was returned to the client because it had been completed incorrectly or key information was missing. Our contact details were provided to the client by Bow County Court when the client visited the court. With appropriate supervision, student advisers assisted the client to check the form had been completed correctly this time. The client was also provided with generic information on the form in question and court procedure.

We subsequently spoke with our client, who had this to say:

"Thank you very much, you have been a star. This has given me a headache since September but now all forms have been accepted by the Court. I just want to say a huge thank you. I wanted to come in personally to thank everyone and would like to keep in touch".

[This extract is reproduced here with the permission of our client].

\section{Case 5: Landlord and tenant dispute (unlawful deduction from rent deposit)}

Our client contacted the Law Clinic for advice on a landlord and tenant matter and wanted to know how to recover a rent deposit paid from a former landlord/landlord's agent.

Our client had entered into a tenancy agreement with a leading estate agent and two weeks after vacating the property they received an email from them detailing damage to the property for which they would be charged. The estate agents 
indicated that they would deduct $£ 330$ from the deposit of $£ 875$. Our client sought advice on the legality of this.

Our student advisers sent a detailed letter of advice and as a result our client informed us that they were given a refund with an agreed deduction of only $£ 100$ for minor repairs to the flat. Our client was very happy with the help the Law Clinic provided them and was glad that the matter was resolved.

Overall we have had many positive responses from our clients and this in turn has motivated both the students and the law school. The students' efforts have been recognised and have given them a sense of achievement.

\section{WHAT ARE THE BENEFITS OF A LIVE CLIENT CLINIC? HOW DOES THIS}

\section{BRIDGE THE GAP?}

The Law Clinic is mainly a vehicle for the study of law and of practice ${ }^{19}$. Although the Law Clinic provides a useful service to the community, it is primarily about putting theory into practice, whilst allowing students time to reflect on their experience. It provides students with an invaluable opportunity to see how a case progresses in practice and how the skills that they will learn on the Legal Practice Course (LPC), for instance, come together in the context of a client's file. This is an ideal way of bridging the gap between university and the Postgraduate Diplomas in Legal Practice and obtaining either a paralegal position or training contract.

\footnotetext{
${ }^{19}$ The Higher Education Academy defines clinical legal education as an experiential form of learning “...in design focused on enabling students to understand how the law works in action by undertaking real, or realistically simulated, casework.": http://www.ukcle.ac.uk/resources/teaching-and-learningpractices/clinic/one/ (last accessed 22/09/2013).
} 
Within a law clinic setting, clinical legal education has also been defined as " $a$ learning environment where students identify, research and apply knowledge in a setting which replicates, at least in part, the world where it is practised... It almost inevitably means that the student takes on some aspect of a case and conducts this as it would ... be conducted in the real world." 20 These definitions of clinical legal education guide our students' experience at UEL's Law Clinic.

There are three principal ways in which our students learn from this clinical experience:

i. work on real clients' cases;

ii. discuss their experience at follow-up meetings; and

iii. evaluate and reflect on their experiences.

Depending on the case, our students have used some or all of the following skills:

- interviewing;

- factual analysis, i.e. problem-solving;

- legal research;

- letter-writing; and

- negotiation and advocacy.

\footnotetext{
${ }^{20}$ Grimes, R. (1996) “The Theory And Practice Of Clinical Legal Education” in Webb, J and Maugham, C (eds.) Teaching Lawyers' Skills, London: Butterworths (p 138) cited by Lewis, R. (2000) "Clinical Legal Education Revisited", Dokkyo International Review, Volume 13, pp149 - 169; also available at $<$ http://hq.ssrn.com/GroupProcesses/RedirectClick.cfm?partid=340484\&corid=649\&runid=8368\&url=http://ssr n.com/abstract=1988997>; < $<$ ttp://ssrn.com/abstract=1988997>; (last access 22/09/2013). Another definition of clinical legal education is "learning by doing the types of things that lawyers do" Brayne, H.(1998) Clinical Legal Education, in Leach, P. (2003) "The effective assessment of clinical legal education" Investigations in University Teaching and Learning, London Metropolitan University, Volume. 1 (2) Winter 2003, 62-65, cited by Jaja, T.C. (2012) Teaching Legislative Drafting: The necessity for clinical legal education, NIALS International Journal of Legislative Drafting (NIJLD), Volume 1 (1), pp 74-87 at 77 available at http://www.nials-nigeria.org/journals/legdraftTonye\%20Clinton\%20Jaja.pdf (last accessed at on 11/07/2014).
} 
Our students have also had the opportunity to develop office and administrative skills, team-working skills and the ability to manage time. In addition, our students have become familiar with some of the ethical and professional issues relevant to legal practice.

At the end of the academic year, a total of eight student advisers at our Law Clinic provided feedback by completing questionnaire and scoring their experience from 1 - 5 (5 being the highest). The students were asked:

\section{Legal Research}

To what extent did the legal research that you conducted for your case improve your legal research skills?

\section{Substantive Law}

Did your participation in Law Clinic work increase your understanding of the law as discussed during the Law Clinic training?

\section{Problem Solving}

Did your participation in Law Clinic work increase your capacity to apply the law to practical problems?

\section{Ethics and Professional Responsibility}

Did your participation in Law Clinic work increase your awareness of the ethical and professional issues affecting a lawyer in practice?

\section{Overall Impression}

How valuable was the experience of your involvement in the Law Clinic?

The results are as follows: 


\section{Legal Research scores out of 5}

- Legal Research

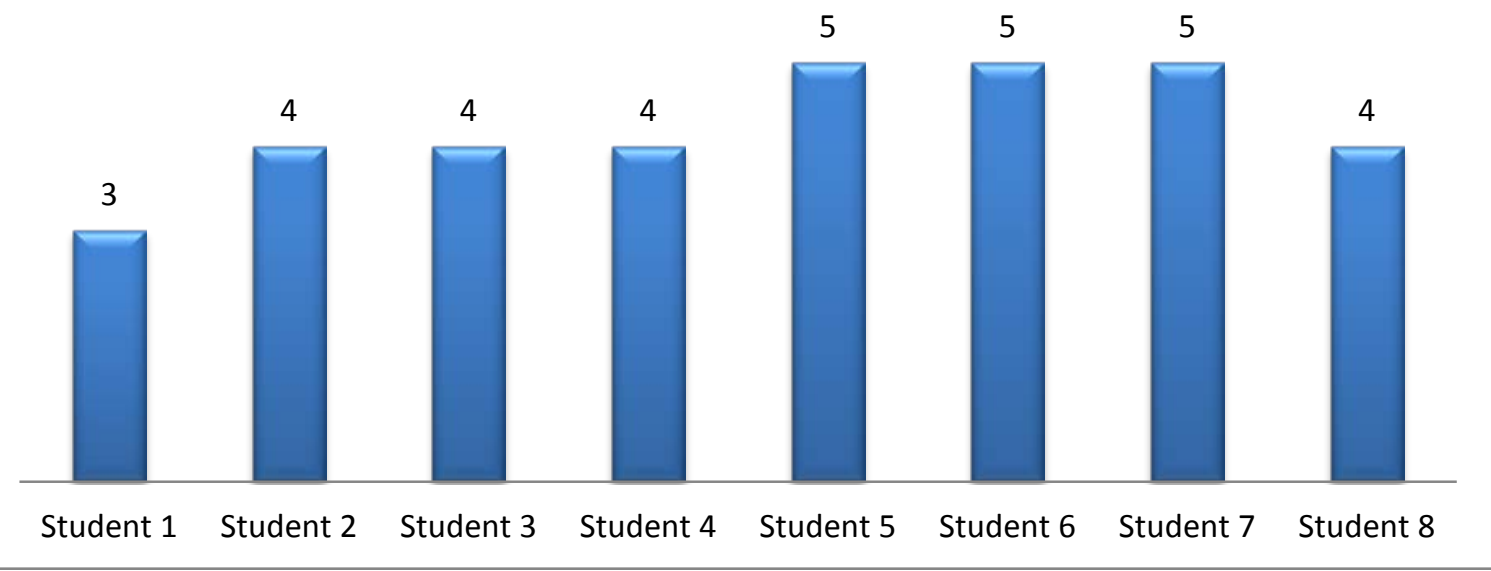

\section{Substantive Law scores out of 5}

$\square$ Substantive Law

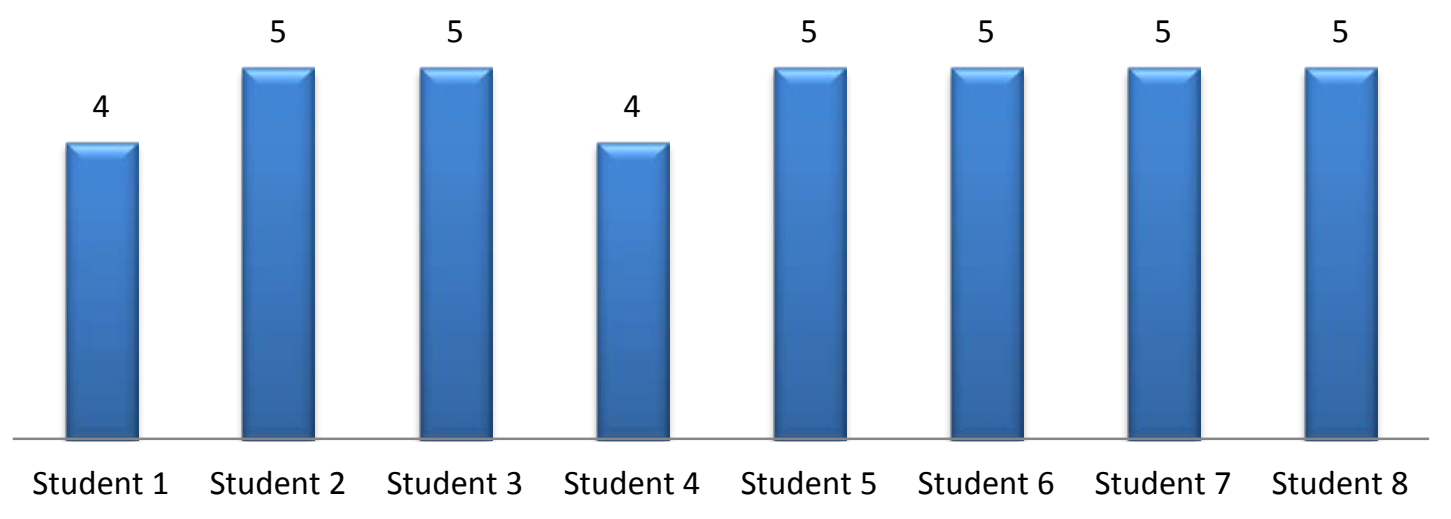




\section{Problem Solving scores out of $\mathbf{5}$}

Problem Solving scores out of 5

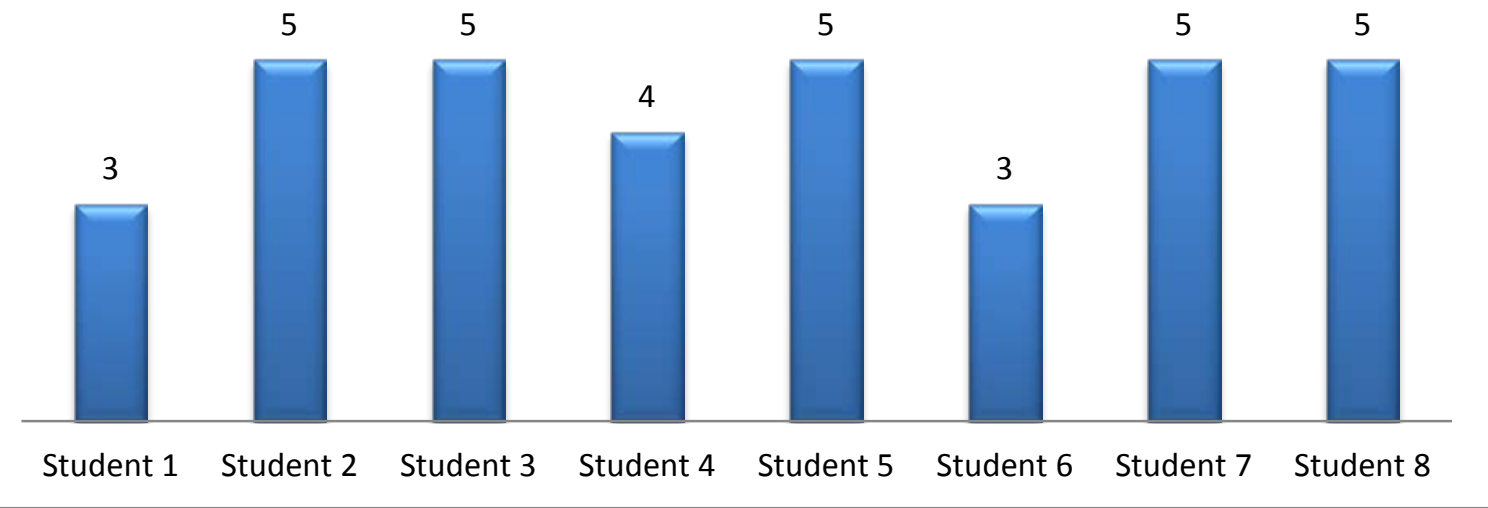

\section{Ethics \& Professional Responsibility scores out of 5}

Ethics \& Professional Responsibility scores out of 5

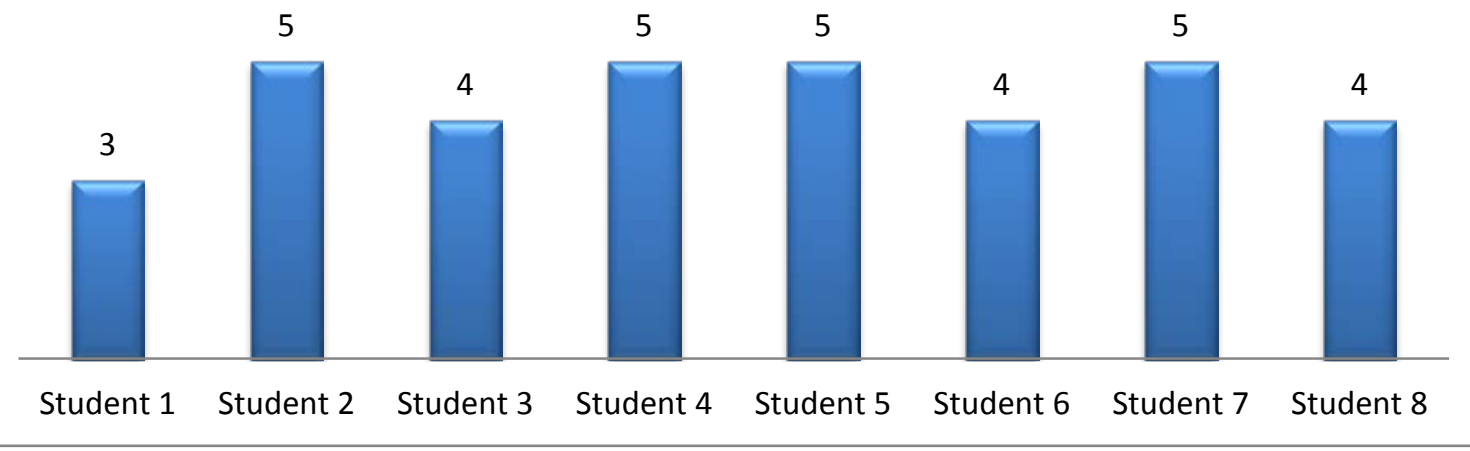

\section{Overall Impression scores out of $\mathbf{5}$}

口 Overall Impression scores out of 5

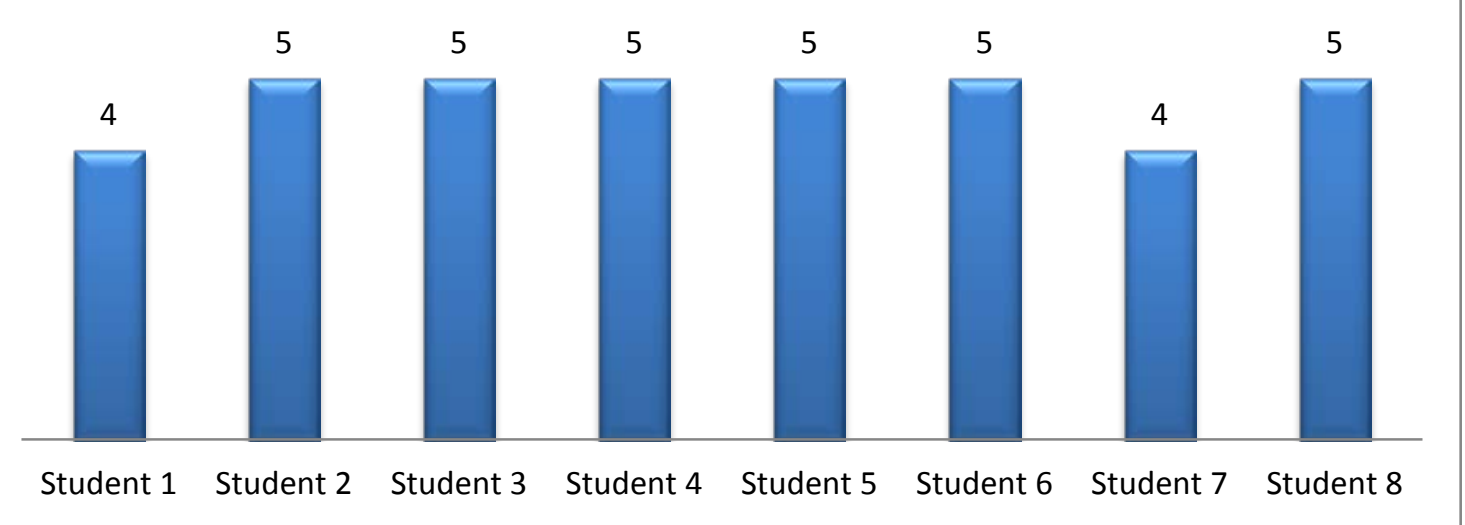


Below are a few extracts from our student advisers about their experiences at the Law Clinic:

"For every advice letter I wrote to the client the supervision has been fantastic. The guidance on how to properly interview the client was clear and specific. I am very proud to be a part of this team and to have such great supervisors to support me", Frederico Maciel

"Being able to deal with real life clients has given me the confidence to step into the real world of work" and "the Supervisors were down to earth and approachable, breaking the student /teacher boundary and communicating with you as a colleague". Kristian Bogdanov

"I enjoyed having the means to help vulnerable people in ways that they could not help themselves".

"I always knew that there was someone who I could ask for advice...My Supervisor encouraged me and was very observant to the work I did ensuring that I felt valued and respected as a student volunteer". Lucie Darrell

"I enjoyed working in a professional and intimate setting and offering advice and aid to help the clients who would come to the Law Clinic... It was helpful and informative to work with the new volunteers and the more experienced advisers...anytime I would attend the Law Clinic Supervisors were always there to assign tasks". Sophia Eyiangho

"On my first interview, the Supervisors provided me with key questions which made the interview flow better. I have gained experience with research and administrative tasks". Ana Leitao

[The above extracts have been reproduced with the students' permission]. 
The results from the student evaluation revealed that our student advisers felt that the experience at the Law Clinic had enhanced their legal research skills; understanding of the law; problem solving skills; and awareness of ethics and professional responsibility.

\section{Previous students}

We have had previous students of the Law Clinic contact us after graduating from the University expressing their views about the positive experience they had at the Law Clinic and the effect that it has had on their job prospects. For example, after securing a position as a Residential Conveyancing Paralegal, Jessica Payne wrote to us to say:

"The experience I gained at the Law Clinic has been a great help to me in interviews and indeed I believe it played a part in helping me secure my new job."

The Law Clinic helped enhance both my confidence and my skills of communication...I have decided that property law is an area I want to focus my skills in and I hope to qualify as a Licensed Conveyancer next year."

\section{WHAT DOES THE FUTURE HOLD?}

We suggest that clinical or experiential form of legal education is increasingly becoming a feature of undergraduate legal education. From the experience of our students, there are many benefits to be gained from actively advising real clients with real problems. This experience enables students to develop transferrable skills for work-life after their studies. Law schools should therefore adequately prepare 
their students for the world of work. We propose that there should be a rethinking of the pedagogical structure of legal education so that some form of clinical experience (our preference being live client clinics) should be added to the curriculum and mainstream courses on the law degree. We suggest that live clinics increase the quality and experience of our students' learning. Kolb defines experiential learning as a "holistic integrative perspective on learning that combines experience, cognition and behaviour". ${ }^{21}$ Kolb argues that learning is a continuous process grounded in experience and a process in which knowledge is generated as new information and experiences are acquired..$^{22}$

Without reflection on experiences, students will not know how to improve. The reflection and evaluation logs that UEL's student advisers complete enables them to make sense of their experience and improve their knowledge and understanding of the law.

Kolb's four stage learning cycle, namely concrete experience, reflective observation, abstract conceptualisation and active experimentation can be clearly identified in the way we run our live client clinic at UEL. Our student advisers have gone through these cycles several times: they have planned, acted, observed and reflected on their work. We believe our student advisers will take this experience with them to their

\footnotetext{
${ }^{21}$ Kolb, D.A. (1984) Experiential learning: Experience as the source of learning and development, Prentice Hall, Englewood Cliffs NJ, p. 21.

${ }^{22}$ Ibid., p. 41.
} 
future places of work and hopefully this will contribute to making them better practitioners.

Lessons are learnt through adaptability and open mindedness; live client clinics enable the students to embrace this rather than a systematic approach to a problem ${ }^{23}$. Advising clients in the local community requires deductive thinking and logical analysis of each case.

Our students learn from their experiences by reflecting and observing what they have done and why. Students are encouraged to use logic and ideas to understand the problems. Students will often draw conclusions and relate them to the law and research they have done. This then leads to action by them writing advice letters.

This hands-on experience that UEL students have had at the Law Clinic has not only boosted their confidence, and improved their research and writing skills, but also increased their employability. Whilst we do not generalise from our own results, they do provide an example where such model live clients clinic can really benefit students. It is possible that in the future, students will benefit more from this experience by gaining credit for their work in the Law Clinic towards their law degree. ${ }^{24}$

\footnotetext{
${ }^{23}$ Akella, D. (2010) Learning together: Kolb's experiential theory and its application, Journal of Management and Organiszation, Volume 16(1), pp.100-112.

${ }^{24}$ Other universities, such Kingston University have already integrated credit bearing law clinic work into their curriculum.
} 


\section{CONCLUSION}

From the aforementioned, we maintain the proposition that live client clinics are beneficial in bridging the skills gap, as the unpredictability of working with real clients allows for a more realistic experience. Live client clinics also offer students the opportunity to acquire legal practice skills they need to successfully pass the vocational stage of their training and use in practice as lawyers.

Furthermore, the live client clinics can be particularly good at providing students with opportunities to examine access to justice, quality of legal services issues, the development of ethical awareness and understanding of professional conduct rules. This enables students to bridge the gap between their theoretical studies and contextual application of law in the real world. In fact, those looking for any career in law will have the benefit of such practical experience.

For those students who choose alternative career paths, skills such as file management, client interview, research, drafting, or office etiquette would still be relevant to most graduate employment.

\section{References}

Akella, D. (2010) Learning together: Kolb's experiential theory and its application, Journal of Management and Organization, Volume 16 (1), 100-112.

Brayne, H. (1998) Clinical Legal Education, in Leach, P. (2003) "The effective assessment of clinical legal education" Investigations in University Teaching and Learning, London Metropolitan University, Vol. 1 (2) Winter 2003, 62-65, cited by Jaja, T.C. (2012) Teaching Legislative Drafting: The necessity for clinical legal education, NIALS International Journal of Legislative Drafting (NIJLD), Volume 1 (1), 74-87.

Evans, A. Cody, A. Copeland, A. Giddings, J. Noone, M.A. and Rice, S. (2012), Best Practices, Australian Clinical Legal Education.

Ferguson, D.D. (2013) The State of Experiential Education, Canadian Law Schools, Manitoba Law Journal, Volume 37 (1), 465 - 471.

Giddings, J. (2010) Why No Clinic Is an Island: The Merits and Challenges of Integrating Clinical Insights Across the Law Curriculum, Journal of Law and Policy, Volume 34, 261-289. 
Grimes, R. (1996) "The Theory And Practice Of Clinical Legal Education" in Webb, J and Maugham, C (eds.) Teaching Lawyers' Skills, London: Butterworths (p 138) cited by Lewis, R. (2000) "Clinical Legal Education Revisited", Dokkyo International Review, Volume 13, 149 - 169

Hinett, K. (2002) Developing Reflective Practice in Legal Education (edited by Tracey Varnava), Coventry: UK Centre for Legal Education.

Kolb, D.A. (1984) Experiential learning: Experience as the source of learning and development, Prentice Hall, Englewood Cliffs NJ.

Robert, D.G., \& Farideh, A.F. (2012) Experiential learning: The internship and Live-Case Study Relationship: Business Education and Accreditation, Volume 4(1), 13-23.

Sturm, S. and Guinier, L. (2007) The law school matrix: Reforming legal education in a culture of competition and conformity, Vanderbilt Law Review, Volume 60 (2), 515-553.

Weigold, U.H. (2006) The Attorney-Client Privilege as an Obstacle to the Professional and Ethical Development of Law Students, Pepperdine Law Review, Volume 33 (3), 676-722.

\section{Online}

Higher Education Academy: http://www.ukcle.ac.uk/resources/teaching-and-learningpractices/clinic/one/ (last accessed 22/09/2013)

Human Rights Lawyer Imran Khan relaunches UEL Law Clinic: http://www.uel.ac.uk/news/pressreleases/2013/11/law-clinic.htm on 29/11/2013 (last accessed 29/11/2013)

London Poverty Profile 2013: http://www.londonspovertyprofile.org.uk/LPP 2013 Report Web.pdf or http://www.londonspovertyprofile.org.uk/LPP 2013 Findings Web.pdf (last accessed 01/04/2014)

New Law Clinic at UEL offers legal advice to the local community: http://www.uel.ac.uk/news/pressreleases/2010/03/community.htm (last accessed 01/04/2014) 